\title{
STUDI KEBERHASILAN PENGELOLAAN OBJEK WISATA BERBASIS COMMUNITY BASED TOURISM (CBT), OBJEK STUDI : PANTAI NGURBLOAT, KABUPATEN MALUKU TENGGARA
}

\author{
Qhalfiah Hairun Bandjar ${ }^{1)}$, B. Irwan Wipranata ${ }^{2)}$, Sylvie WIrawati ${ }^{3)}$ \\ 1)Program Studi S1 PWK, Fakultas Teknik, Universitas Tarumanagara, qhalfiahbandjar@gmail.com \\ 2) Program Studi S1 PWK, Fakultas Teknik, Universitas Tarumanagara, irwan_wipranata@yahoo.co.uk \\ 3) Program Studi S1 PWK, Fakultas Teknik, Universitas Tarumanagara, sylview@ft.untar.ac.id
}

\begin{abstract}
Abstrak
Salah satu wilayah di Indonesia yang memiliki potensi wisata alam adalah Indonesia bagian Timur, dimana Indonesia Timur memiliki potensi wisata alam yang indah walaupun masih sedikit pembangunan yang dilakukan, seperti Provinsi Maluku. Salah satu sektor pendapatan daerah Provinsi Maluku adalah sektor pariwisata karena memiliki potensi di bidang pariwisata, selain itu dapat dilihat dari jumlah wisatawan yang meningkat sebesar $10 \%$ tiap tahunnya. Hal ini menunjukkan Provinsi Maluku memiliki keunggulan di sektor pariwisata terutama wisata bahari, salah satu daerah di Provinsi Maluku yang memiliki potensi yaitu Kabupaten Maluku Tenggara dengan objek wisata Pantai Ngurbloat. Pantai Ngurbloat merupakan objek wisata dengan menerapkan konsep Community Based Tourism (CBT) yang pengolahannya melibatkan masyarakat desa, kelompok sadar wisata dan pihak pengelola. Dengan pengelolaan berbasis CBT, Pantai Ngurbloat telah mendapatkan 3 penghargaan, salah satunya menjadi wisata terbaik di Kabupaten Maluku Tenggara. Tujuan utama dari penelitian ini adalah untuk mengetahui faktor-faktor keberhasilan pengelolaan objek wisata Pantai Ngurbloat yang berbasis CBT. Penelitian ini merupakan penelitian deskriptif dengan kombinasi pendekatan kualitatif dan kuantitatif. Pendekatan kualitatif dilakukan dengan cara survey lapangan dan wawancara mendalam (in-depth interview) dengan pihak terkait sedangkan pendekatan kuantitatif dilakukan dengan pengisian kuesioner oleh wisatawan objek wisata Pantai Ngurbloat. Terdapat lima analisis yang digunakan pada penelitian ini yaitu analisis lokasi, analisis daya tarik, analisis persepsi dan preferensi, analisis pengelolaan berbasis Community Based Tourism (CBT) dan analisis faktor-faktor keberhasilan pengelolaan berbasis CBT. Hasil dari penelitian ini berupa 6 faktor terkait konsep CBT dari 10 faktor-faktor yang mempengaruhi keberhasilan dalam pengelolaan objek wisata Pantai Ngurbloat berbasis Community Based Tourism (CBT).
\end{abstract}

\section{Kata kunci: Faktor-faktor keberhasilan; Pantai Ngurbloat; Pariwisata berbasis masyarakat}

\begin{abstract}
One of regions in Indonesia that have natural tourism potential are Eastern Indonesia, where Eastern Indonesia has beautiful natural tourism potential although there is still little development being done, such as Maluku Province. One of the regional income sectors of Maluku Province is the tourism sector because it has potential in the field of tourism, besides that it can be seen from the number of tourists visiting who increase by $10 \%$ every year. This shows that Maluku Province has advantages in the tourism sector, especially marine tourism, one of the areas in Maluku Province that has potential is Southeast Maluku Regency with Ngurbloat Beach tourist attraction. Ngurbloat Beach is a tourist attraction by applying the concept of Community Based Tourism (CBT) whose management involves village communities, tourism awareness groups and the management. With CBT-based management, Ngurbloat Beach has received 3 awards, one of which is being the best tourism object in Southeast Maluku Regency. The main purpose of this study was to determine the success factors for managing CBT-based Ngurbloat Beach tourism objects. This research is a descriptive research with qualitative and quantitative approaches. The
\end{abstract}


qualitative approach was carried out by means of field surveys and in-depth interviews with related parties. The quantitative approach was done by having tourists fill out questionnaires at the Ngurbloat Beach tourist attraction. There are five methods of analysis used in this study, namely location analysis, attractiveness analysis, perception and preference analysis, analysis of management based on Community Based Tourism (CBT) and analysis of the success factors of CBT-based management. The results of this research are in the form of factors that influence the success in managing Ngurbloat Beach tourism objects based on Community Based Tourism (CBT).

\section{Keywords: Community Based Tourism; Ngurbloat beach; Success factors}

\section{PENDAhUluAN}

\section{Latar Belakang}

Salah satu wilayah di Indonesia yang terkenal dengan potensi wisata alam adalah Indonesia bagian Timur. Dimana Indonesia bagian Timur memiliki potensi wisata yang indah, salah satunya Provinsi Maluku. Salah satu sektor pendapatan daerah Provinsi Maluku adalah sektor pariwisata dikarenakan memiliki potensi di bidang pariwisata menjadikan peningkatan PDRB di Provinsi Maluku. Selain dilihat dari peningkatan PDRB, keunggulan pariwisata di Provinsi Maluku juga dapat dilihat dari jumlah wisatawan yang terus meningkat tiap tahunnya. Hal ini menunjukkan bahwa Provinsi Maluku memiliki keunggulan dalam sektor pariwisata terutama wisata bahari.

Salah satu daerah di Provinsi Maluku yang memiliki potensi wisata bahari adalah Kabupaten Maluku Tenggara yaitu objek wisata Pantai Ngurbloat yang terletak di Desa Ngilngof, Kecamatan Manyeuw. Di Kabupaten Maluku Tenggara memiliki ciri khas yaitu penguasaan tanah berdasarkan petuanan atau penguasaan tanah oleh masyarakat hukum adat, sehingga Pantai Ngurbloat merupakan salah satu objek wisata pantai yang dikembangkan dan dikelola oleh masyarakat desa secara swadaya. Dengan dikembangkan dan dikelola oleh masyarakat Desa Ngilngof membuat Dinas Pariwisata Kabupaten Maluku Tenggara melihat potensi wisata dan membuat pengelolaan berbasis Community Based tourism (CBT).

Community Based Tourism (CBT) sendiri merupakan pariwisata mengenai kelestarian lingkungan, sosial dan budaya sekitar yang dikelola dan dimiliki masyarakat dan untuk masyarakat itu sendiri. Pantai Ngurbloat merupakan salah satu objek wisata bahari yang menerapkan pengelolaan berbasis Community Based Tourism (CBT) yang berlokasi di Desa Ngilngof, Kecamatan Manyeuw, Kabupaten Maluku Tenggara, Provinsi Maluku. Pantai Ngurbloat memiliki panjang pantai $\pm 3 \mathrm{~km}$ dengan memiliki luas $\pm 22.370 \mathrm{Ha}$ yang telah ditetapkan oleh pengelola yang mengelola Pantai Ngurbloat.

Keindahan alam dan pengelolaan Pantai Ngurbloat membuat Pantai Ngurbloat telah mendapatkan 3 penghargaan, baik dari National Geographic yang mengakui kehalusan pasir yang berada di Pantai Ngurbloat, Kementerian Pariwisata RI yang menganugerahi Pantai Ngurbloat sebagai surga tersembunyi terpopuler (Most Popular Hidden Paradise) dan pada tahun 2017 Pantai Ngurbloat telah dinobatkan sebagai wisata terbaik di Kabupaten Maluku Tenggara. Selain itu, Pantai Ngurbloat juga masuk dalam kawasan strategis pariwisata yang tertera dalam RPJMD 201 - 2023 Kabupaten Maluku Tenggara.

\section{Rumusan Permasalahan}

Rumusan masalah dalam penelitian ini adalah potensi dan faktor-faktor yang mempengaruhi keberhasilan dalam pengelolaan objek wisata Pantai Ngurbloat berbasis Community Based Tourism (CBT). Objek wisata Pantai Ngurbloat dinobatkan sebagai wisata terbaik di Kabupaten Maluku Tenggara, menunjukkan bahwa adanya keberhasilan pengelolaan yang diterapkan pada objek wisata Pantai Ngurbloat. Dengan adanya keberhasilan tersebut, membuat adanya pertanyaan terkait dengan potensi dan faktor-faktor apa saja yang mempengaruhi keberhasilan pengelolaan berbasis Community 
Based Tourism (CBT) dikarenakan dengan berkembangnya dan tercapainya keberhasilan pengelolaan Pantai Ngurbloat mampu meningkatkan kesejahteraan masyarakat Desa Ngilngof.

\section{Tujuan}

Adapun tujuan penelitian ini adalah mengidentifikasi potensi dan faktor-faktor yang mempengaruhi keberhasilan pengelolaan objek wisata Pantai Ngurbloat berbasis Community Based Tourism (CBT).

\section{KAJIAN LITERATUR}

\section{Pariwisata}

Pariwisata merupakan perjalanan untuk mendapatkan kesenangan sehingga jika dalam perjalanan tersebut tidak mendapatkan kesenangan maka tidak dapat dikatakan sebagai perjalanan wisata (Yoeti, 2010). Menurut Undang-undang No. 10 Tahun 2009 tentang kepariwisataan, terdapat beberapa jenis wisata yaitu wisata alam dan wisata sosial-budaya. Terdapat beberapa komponen-komponen wisata yang berada dalam suatu objek wisata, antara lain (1) atraksi, yaitu berupa salah satu daya tarik wisata yang menyediakan kegiatan pariwisata; (2) Akomodasi, yaitu salah satu fasilitas pendukung pariwisata; (3) Aksesibilitas, yaitu kemudahan untuk menjangkau suatu objek wisata; (4) Fasilitas penunjang, yaitu fasilitas yang menunjang kelancaran sebuah wisata (Warpani, 2006).

Menurut Yoeti (1996) suatu objek wisata memiliki daya tarik untuk dikunjungi apabila sudah memenuhi syarat-syarat sebagai sebagai berikut; (1) something to see, di objek wisata tersebut memiliki atraksi wisata yang berbeda dibandingkan dengan objek wisata lain atau dapat dikatakan bahwa objek wisata tersebut memiliki daya tarik khusus atau ciri khas; (2) something to do, di objek wisata tersebut memiliki banyak hal yang dapat dilakukan, salah satunya dengan menyediakan fasilitas rekreasi atau kegiatan yang dapat dilakukan oleh wisatawan untuk beraktifitas; (3) something to buy, di objek wisata tersebut terdapat fasilitas untuk berbelanja yang merupakan barang ciri khas objek wisata tersebut.

\section{Community Based Tourism (CBT)}

Community Based Tourism (CBT) adalah pariwisata mengenai kelestarian lingkungan, sosial dan budaya sekitar yang dikelola dan dimiliki masyarakat dan untuk masyarakat itu sendiri agar wisatawan dapat memiliki kesadaran untuk belajar tentang masyarakat dan cara hidup masyarakat lokal. CBT merupakan jenis pariwisata yang memiliki keunikan dengan pariwisata lainnya, CBT lebih mementingkan dampak pariwisata terhadap sumber daya lingkungan dan masyarakat dibandingkan untuk memaksimalkan keuntungan bagi investor (Rest, 1999). CBT merupakan strategi pengembangan dari masyarakat yang menggunakan pariwisata untuk memperkuat organisasi masyarakat dalam pengelolaan sumber daya pariwisata dengan masyarakat yang berpartisipasi.

Yaman dan Mohd (2004) menjelaskan terdapat beberapa kunci pariwisata yang melakukan pendekatan secara Community Based Tourism (CBT) antara lain; (1) adanya dukungan pemerintah; (2) partisipasi masyarakat; (3) pembagian keuntungan yang adil; (4) penggunaan sumber daya lokal secara berkesinambungan; (5) penguatan institusi lokal. Menurut Karacaoglu dan Birdie (2017) menyebutkan terdapat 10 faktor yang menjadikan sukses keberhasilan dari pengelolaan berbasis Community Based Tourism (CBT). Faktor-faktor keberhasilan pengelolaan berbasis Community Based Tourism, ditunjukkan pada tabel 1.

Tabel 1. Faktor-faktor Keberhasilan Pengelolaan Berbasis Community Based Tourism

\begin{tabular}{cll}
\hline No & \multicolumn{1}{c}{ Faktor-Faktor } & \multicolumn{1}{c}{ Indikator } \\
\hline 1 & Kepuasan wisatawan & Kepuasan wisatawan dari berbagai aspek \\
\hline 2 & $\begin{array}{l}\text { Hubungan antar masyarakat satu } \\
\text { sama lain }\end{array}$ & $\begin{array}{l}\text { Berdasarkan pertemanan individu dan jaringan keluarga } \\
\text { anggota masyarakat }\end{array}$ \\
\hline 3 & Keaslian lokal & Identitas budaya otentik dan warisan budaya yang unik \\
\cline { 2 - 3 }
\end{tabular}




\begin{tabular}{|c|c|c|}
\hline 4 & Keunikan lokal & Tercipta perbedaan dengan objek wisata lain \\
\hline 5 & Kepemilikan lokal & Masyarakat sebagai pemilik sumber daya budaya dan alam \\
\hline 6 & Kepemimpinan lokal & $\begin{array}{l}\text { Pemimpin lokal mengelola, mengarahkan dan membangun } \\
\text { hubungan antara masyarakat dan stakeholders }\end{array}$ \\
\hline 7 & Dukungan masyarakat & $\begin{array}{l}\text { Dukungan masyarakat dalam tahap perencanaan, } \\
\text { perangkulan, implementasi dan evaluasi keberhasilan }\end{array}$ \\
\hline 8 & Skala pengembangan pariwisata & $\begin{array}{l}\text { Pengembangan dan pengelolaan pariwisata sesuai dengan } \\
\text { prioritas, tuntutan, dan sumber daya masyarakat }\end{array}$ \\
\hline 9 & Kerjasama antar stakeholders & Masyarakat dan stakeholders berkolaborasi \\
\hline 10 & $\begin{array}{l}\text { Dukungan eksternal dari } \\
\text { stakeholders }\end{array}$ & $\begin{array}{l}\text { Stakeholders memberikan dukungan untuk meningkatkan } \\
\text { kapasitas }\end{array}$ \\
\hline
\end{tabular}

Sumber : Karacaoglu dan Birdie (2017)

\section{Kelompok Sadar Wisata (Pokdarwis)}

Menurut Buku Pedoman Kelompok Sadar Wisata (2012), Kelompok sadar wisata (Pokdarwis) adalah sebuah kelembagaan masyarakat yang memiliki anggota para pelaku kepariwisataan yang peduli dan bertanggung jawab serta memiliki peran sebagai penggerak untuk mendukung terciptanya keadaan yang kondusif untuk kepariwisataan dan terwujudnya sapta pesona dalam peningkatan pembangunan daerah melalui pariwisata dan bermanfaat bagi kesejahteraan masyarakat sekitar dan Pokdarwis memiliki peran dalam CBT dibagi menjadi 3 yaitu peran dalam tahapan perencanaan, peran dalam tahapan implementasi dan peran dalam tahap pemanfaatan (Soekanto, 2007)

\section{Badan Usaha Milik Ohoi (BUMO)}

Dalam Peraturan Bupati Maluku Tenggara No. 11 Tahun 2019 tentang tata cara pendirian, pengurusan, pengelolaan dan pembubaran Badan Usaha Milik Ohoi (BUMO) mengatakan BUMO adalah badan usaha yang sebagian besar/seluruh modal dimiliki oleh ohoi/ohoi soa melalui penyertaan secara langsung yang berasal dari kekayaan ohoi/ohoi soa yang dipisahkan guna mengelola asset, jasa pelayanan, dan usaha lainnya untuk sebesar-besarnya kesejahteraan masyarakat ohoi/ohoi soa. Untuk pemenuhan modal usaha BUMO dapat mengajukan pinjaman modal kepada pihak lain, seperti dari Pemerintah desa dan lain-lain. Badan Usaha Milik Ohoi dilakukan oleh pemerintah desa dan masyarakat

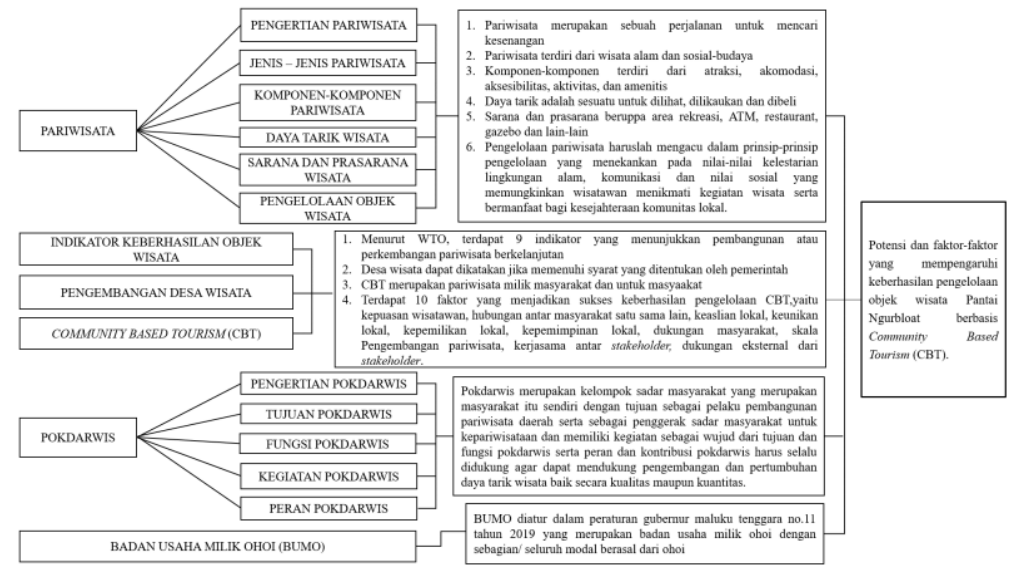

Gambar 1. Kerangka Teori

Sumber : Hasil Olahan Penulis, 2021

\section{METODE}

Metode penelitian yang digunakan pada penelitian ini adalah metode deskriptif dengan kombinasi pendekatan kualitatif dan kuantitatif. Penelitian deskriptif merupakan penelitian yang menggambarkan suatu masalah atau fenomena secara rinci melalui metode kualitatif, yang artinya data penelitian dikumpulkan dengan cara studi literatur ataupun wawancara mendalam dengan pihakpihak terkait seperti pemerintah Desa Ngilngof, BUMO, Pokdarwis dan Pengelola. Metode kuantitatif 
dengan cara pengisian kuesioner oleh wisatawan objek wisata Pantai Ngurbloat.

Populasi (N) dari penelitian ini adalah wisatawan objek wisata Pantai Ngurbloat. Untuk pengambilan sampel (n) diambil dengan menggunakan teknik random sampling atau sampel acak. Jumlah sampel yang diambil menggunakan teknik perhitungan Slovin didapatkan sampel sebesar 100 orang.

Untuk analisis yang digunakan pada penelitian ini adalah analisis lokasi, analisis daya tarik, analisis persepsi dan preferensi, analisis pengelolaan berbasis Community Based Tourism (CBT) dan analisis faktor-faktor keberhasilan pengelolaan berbasisi CBT.

\section{Objek Penelitian}

Penelitian ini dilakukan pada objek penelitian tentang pengelolaan objek wisata Pantai Ngurbloat di Desa Ngilngof, Kecamatan Manyeuw, Kabupaten Maluku Tenggara, Provinsi Maluku. Objek wisata Pantai Ngurbloat merupakan salah satu daya tarik wisata yang terdapat di Desa Ngilngof, Kecamatan Manyeuw, Kabupaten Maluku Tenggara, Provinsi Maluku. Luas objek wisata Pantai Ngurbloat yang ditetapkan oleh pengelola Pantai Ngurbloat adalah seluas $\pm 22.370 \mathrm{Ha}$. Objek wisata Pantai Ngurbloat dikelola oleh pengelola Pantai Ngurbloat sebagai pengelola khusus Pantai Ngurbloat.

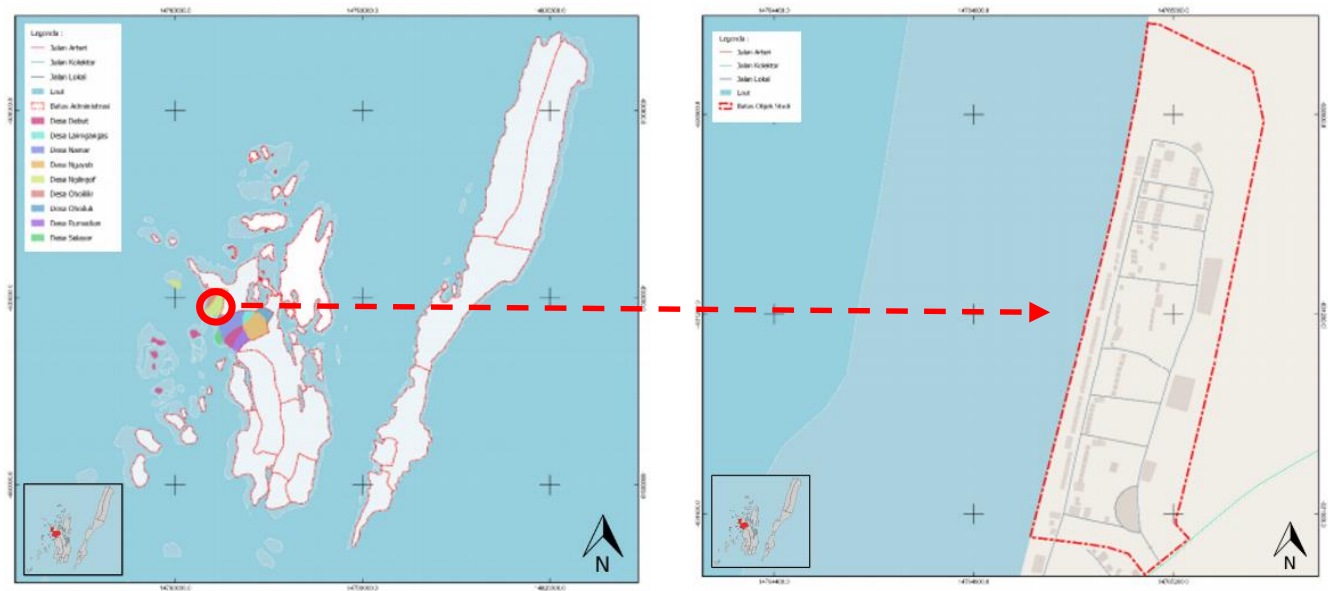

Gambar 2. Kecamatan Manyeuw (kiri) dan Lokasi Objek Wlsata (kanan) Sumber : Hasil Olahan Penulis, 2021
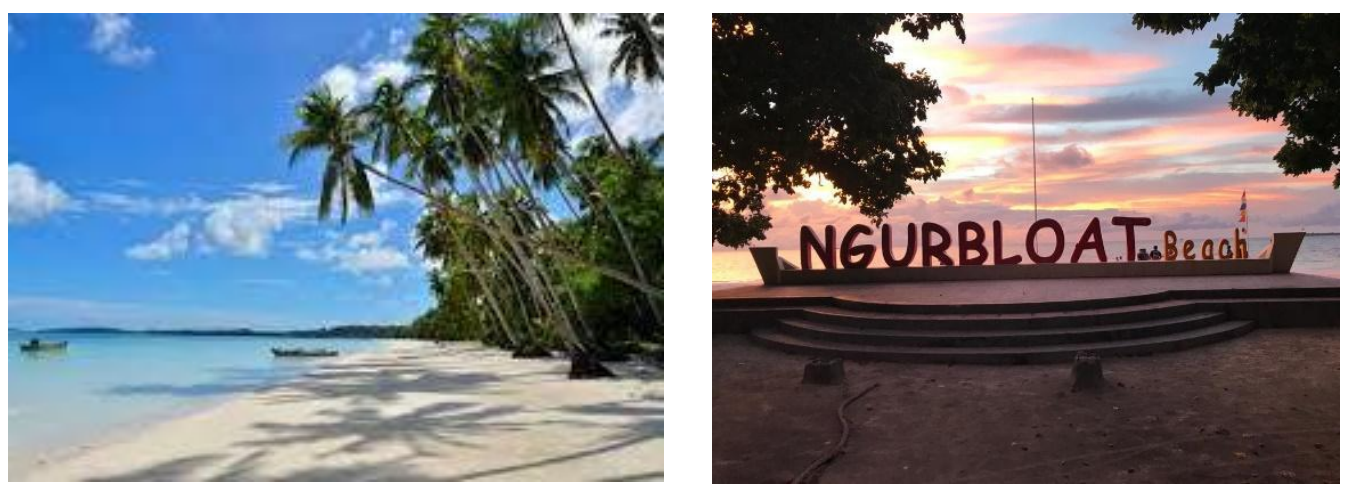

Gambar 3. Objek Wisata Pantai Ngurbloat

Sumber : Penulis, 2021

\section{DISKUSI DAN HASIL}

\section{Analisis Lokasi}

Objek wisata Pantai Ngurbloat dapat diakses dengan mudah karena lokasinya yang dapat diakses melalui jalur darat dengan menggunakan transportasi pribadi seperti mobil dan motor yang menghubungkan Pelabuhan Tual, Bandara Karel Sadsuitubun, Pusat Kota Langgur dan Pusat Kota Tual melalui jalan kabupaten dengan jarak tempuh $\pm 12.7 \mathrm{~km}$ sampai dengan $16.7 \mathrm{~km}$ dan ditempuh dengan waktu \pm 25 sampai 30 menit, namun belum tersedia transportasi umum untuk menuju objek 
wisata Pantai Ngurbloat sehingga hanya dapat menggunakan transportasi pribadi. Selain itu, pada objek wisata Pantai Ngurbloat juga memiliki keterdekatan dengan fasilitas-fasilitas yang berada di dalam kawasan objek wisata Pantai Ngurbloat. Terdapat 13 cottage dan 4 café \& resto yang berada dalam radius $\pm 1 \mathrm{~km}$ dari objek wisata Pantai Ngurbloat. Dapat dilihat pada gambar 3 .
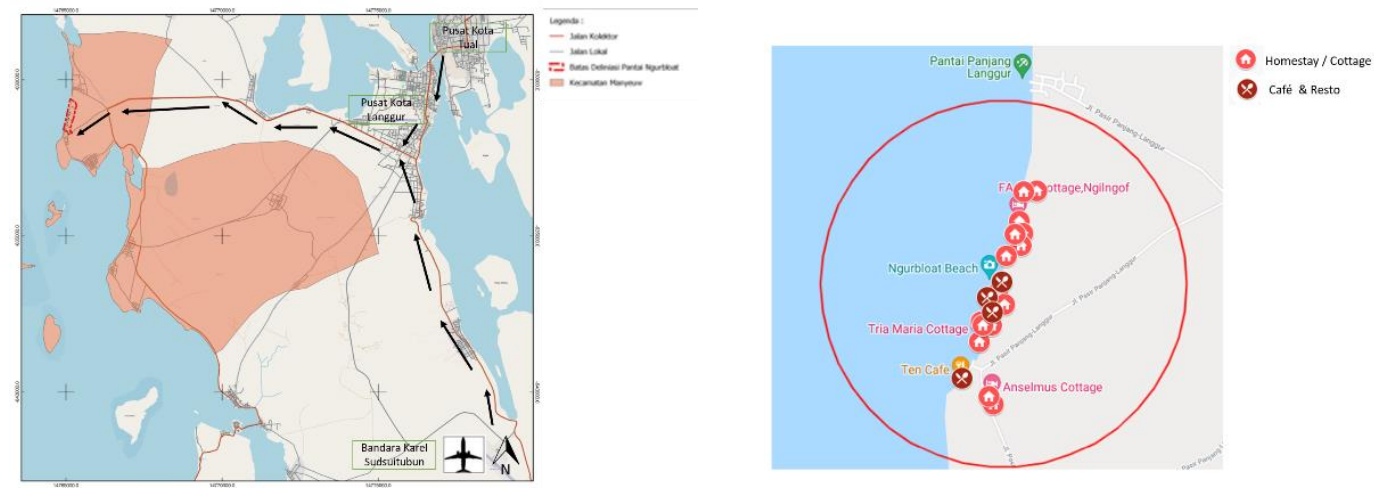

Gambar 4. Peta Aksesibilitas (kiri) dan Peta Proximity (kanan) Sumber : Hasil Olahan Penulis, 2021

\section{Analisis Daya Tarik}

Suatu objek wisata memiliki daya tarik untuk dikunjungi apabila memenuhi syarat-syarat sebagai berikut :

1. Something to see

Objek wisata Pantai Ngurbloat memiliki keindahan alam baik pemandangan seperti pasir yang halus seperti tepung dan laut yang biru maupun keindahan bawah lautnya yang memiliki banyak flora dan fauna yang dapat memanjakan mata wisatawan jika snorkeling di objek wisata tersebut.
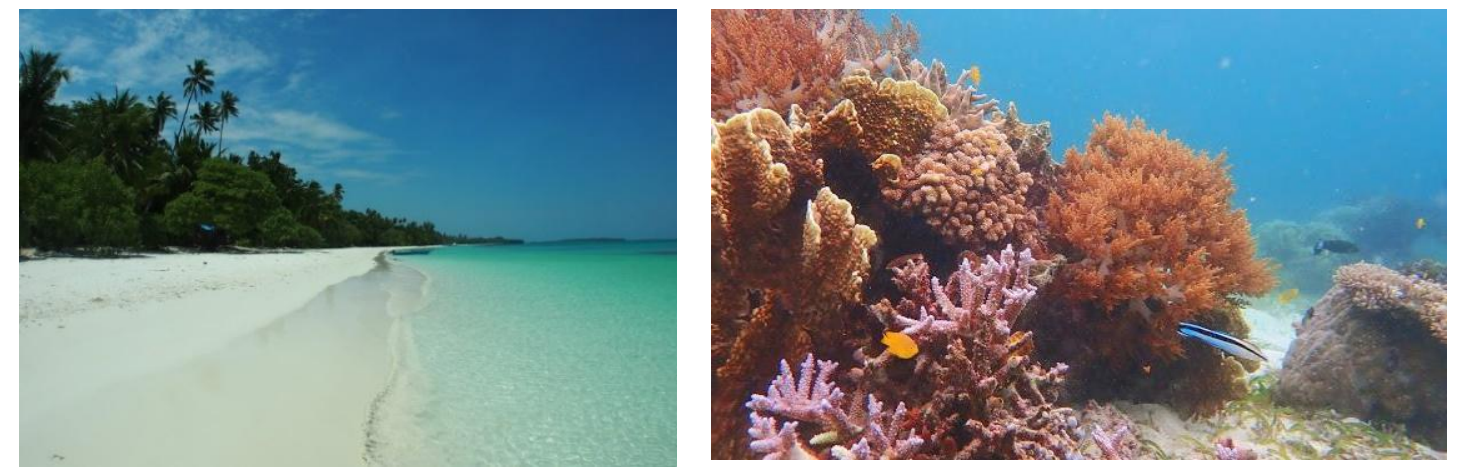

Gambar 5. Keindahan Pemandangan (kiri) dan Keindahan Bawah Laut (kanan) Sumber : Penulis, 2021

\section{Something to do}

Pada objek wisata Pantai Ngurbloat merupakan objek wisata yang memanfaatkan kondisi alam sehingga disediakan beberapa kegiatan yang dilakukan di Pantai Ngurbloat yaitu menikmati keindahan pemandangan, menikmati keindahan bawah laut dengan snorkling, menikmati wisata kuliner yang disediakan, serta adanya balai kesenian Ngurbloat yang dapat menjadi tempat penyelenggara event dan terdapat pula beberapa spot foto agar dapat menjadi kenang-kenangan telah mengunjungi objek wisata Pantai Ngurbloat. 

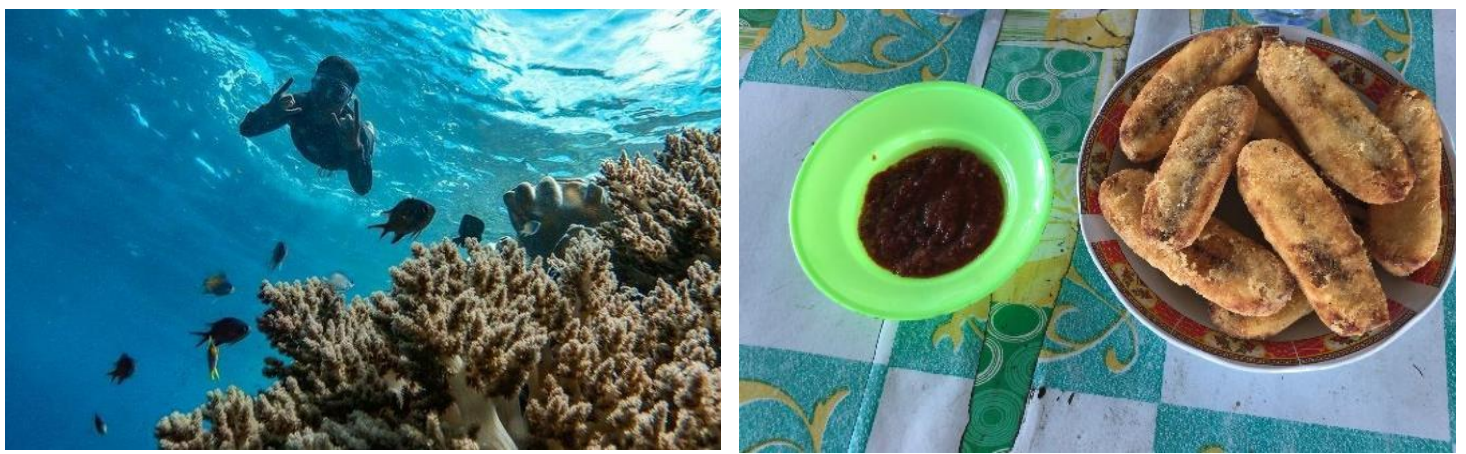

Gambar 6. Kegiatan Snorkeling (kiri) dan wisata kuliner (kanan)

Sumber : Penulis, 2021

Selain aktivitas-aktivitas itu, para wisatawan dapat juga menginap di kawasan objek wisata Pantai Ngurbloat dikarenakan terdapat beberapa cottage yang berada di kawasan objek wisata. Cottage yang tersedia di objek wisata Pantai Ngurbloat memiliki tema/suasana yang berbeda sehingga para wisatawan dapat memilih ingin menginap di cottage dengan nuansa vintage yang memiliki bangunan dari kayu-kayu asli atau nuansa modern yang disajikan oleh pemilik usaha cottage.
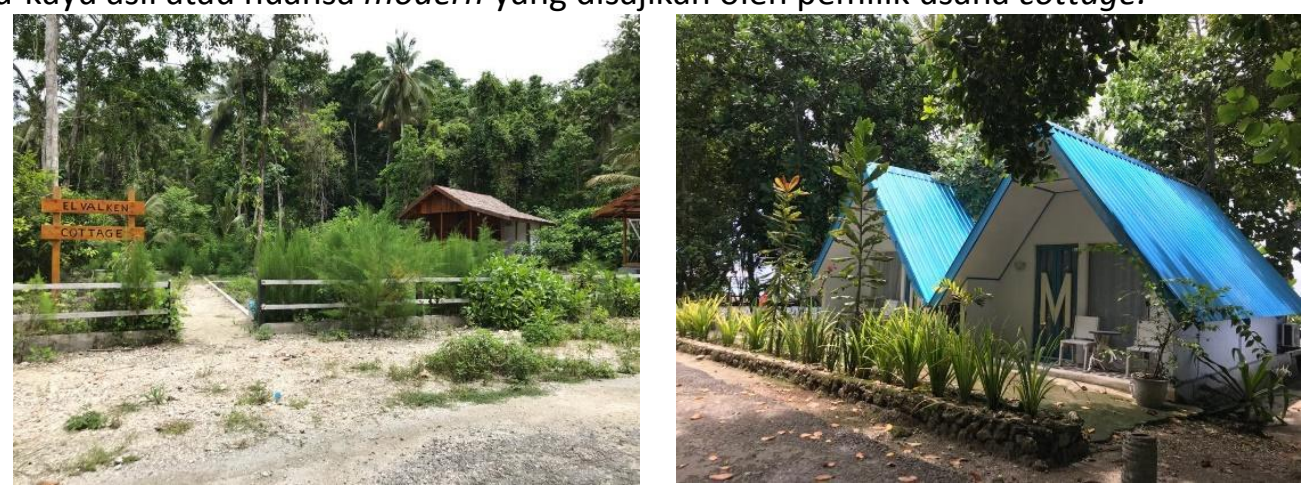

Gambar 7. Cottage di Objek Wisata Pantai Ngurbloat

Sumber : Penulis, 2021

\section{Something to buy}

Terdapat oleh-oleh khas Kabupaten Maluku Tenggara yang dapat para wisatawan beli pada Pantai Ngurbloat seperti kaos yang bertulisan evav yang merupakan bahasa daerah masyarakat lokal, gelanggelang, akar bahar yang berasal dari pohon kasuari, mutiara air asin dan kerajinan kulit kerang yang dijadikan hiasan dinding, lukisan, gelang, anting dan lain-lain. Selain itu, terdapat pula oleh-oleh berupa makanan khas daerah seperti embal yang memiliki dua varian yaitu embal original dan embal yang telah dimodifikasi dengan bahan lain dan kacang botol.

\section{Analisis Persepsi dan Preferensi}

Analisis persepsi dilakukan menggunakan metode IPA (Importance Performance Analysis) dan CSI (Customer Satisfaction Index) yang dihitung dengan skala likert dari hasil penyebaran kuesioner pada wisatawan objek wisata Pantai Ngurbloat. Berdasarkan hasil perhitungan CSI, mendapatkan nilai kepuasan responden adalah sebesar $72.34 \%$ yang menyatakan bahwa responden sebagai sampel wisatawan objek wisata Pantai Ngurbloat merasa puas dengan faktor-faktor kepuasan wisatawan yang terdapat pada kuesioner yang disebarkan.

Usulan wisatawan didapatkan pula pada hasil penyebaran kuesioner terkait dengan kegiatan wisata dan fasilitas yang perlu ditambahkan pada objek wisata. Untuk kegiatan wisata yang perlu ditambahkan dari hasil kuesioner yang diisi oleh responden adalah $45 \%$ responden menyatakan perlunya penambahan kegiatan water sport dan $50 \%$ menyatakan perlu menambahkan fasilitas ATM Center. 


\section{Analisis Pengelolaan Berbasis Community Based Tourism (CBT)}

Terdapat beberapa kunci pariwisata yang melakukan pendekatan secara Community Based Tourism (CBT), yaitu :

a. Adanya dukungan pemerintah

Keberadaan objek wisata Pantai Ngurbloat hingga saat ini tak lepas dari adanya dukungan pemerintah setempat dan pemerintah daerah. Dapat dilihat dari adanya peraturan dan hukum adat istiadat yang mendukung berkembangnya objek wisata Pantai Ngurbloat serta adanya bantuan dari beberapa pihak seperti Pemerintah Kabupaten Maluku Tenggara dan PT. Telkom.

\section{b. Partisipasi masyarakat}

Berdasarkan hasil wawancara dengan pihak pengelola Pantai Ngurbloat, pengelolaan objek wisata Pantai Ngurbloat tidak lepas dari keterlibatan masyarakat Desa Ngilngof. Dapat dilihat dari banyaknya masyarakat desa yang berpartisipasi dalam pengelolaan dan usaha di Pantai Ngurbloat. Bentuk partisipasi masyarakat Desa Ngilngof dalam pengelolaan objek wisata Pantai Ngurbloat adalah sebagai pihak pengelola Pantai Ngurbloat dan pelaku usaha yang bekerja secara langsung di objek wisata Pantai Ngurbloat, sedangkan partisipasi masyarakat dalam bentuk lainnya yaitu menjadi perangkat BUMO atau Pokdarwis sebagai unit Desa Ngilngof dan tidak bekerja secara langsung di objek wisata.

\section{c. Pembagian keuntungan yang adil}

Berdasarkan hasil wawancara dengan pihak pengelola Pantai Ngurbloat mengatakan bahwa pendapatan objek wisata Pantai Ngurbloat secara keseluruhan berasal dari beberapa sumber, namun sumber utama yaitu tiket masuk dan biaya parkir pada objek wisata tersebut. Pembagian keuntungan dari pendapatan tersebut dibagi untuk beberapa pihak yang bekerjasama dengan pihak pengelola Pantai Ngurbloat. Hal ini ditunjukkan pada gambar 6.

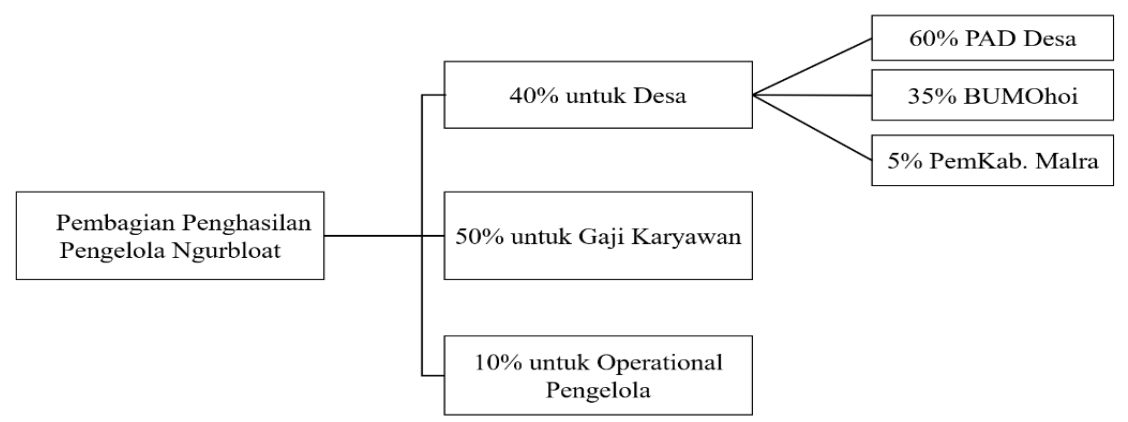

Gambar 8. Sistem Pembagian Pendapatan Pantai Ngurbloat Sumber : Hasil Olahan Penulis

Berdasarkan gambar 6, menurut pihak pengelola Pantai Ngurbloat bahwa keuntungan yang didapatkan oleh objek wisata Pantai Ngurbloat telah terbagi secara merata dan asil, dimana setiap stakeholder/ pihak-pihak terkait mendapatkan keuntungan sesuai dengan peran masing-masing.

\section{d. Penggunaan sumber daya lokal secara berkesinambungan}

Berdasarkan hasil wawancara dengan Kelompok Sadar WIsata (Pokdarwis) mengatakan, sejak awal objek wisata Pantai Ngurbloat dibuka sebagai objek wisata. Masyarakat Desa Ngilngof ikut memiliki peran dalam pengelolaan objek wisata tersebut, baik menjadi karyawan pengelola, pelaku usaha, maupun terlibat dalam perangkat-perangkat desa seperti perangkat Desa Ngilngof, Badan Usaha Milik Ohoi (BUMO) dan Kelompok Sadar Wisata (Pokdarwis). Dengan terlibatnya masyarakat dalam pengelolaan menunjukkan penggunaan sumber daya manusia (SDM) lokal. Selain itu, penggunaan sumber daya alam (SDA) lokal juga ditunjukkan dengan adanya promosi objek wisata lain selain Pantai Ngurbloat yang dilakukan oleh komunitas lokal. Masyarakat Desa Ngilngof juga merasa memiliki dan menjaga kondisi alam objek wisata dengan cara menjaga kebersihan objek wisata dan tidak mengganggu ekosistem/alam pada objek wisata Pantai Ngurbloat. 


\section{e. Penguatan institusi lokal}

Berdasarkan hasil wawancara dengan Kepala Desa Ngilngof mengatakan, dengan adanya Badan Usaha Milik Ohoi (BUMO) dan Kelompok Sadar Wisata (Pokdarwis) serta pengelola yang membantu membina masyarakat dalam mengembangkan objek wisata Pantai Ngurbloat memiliki manfaat tersendiri. Ketiga unit desa tersebut mempunyai beberapa anggota masyarakat Desa Ngilngof sehingga membuat hubungan antar masyarakat terjaga dan memaksimalkan sumber daya manusia yang ada. Pembinaan yang dilakukan kepada masyarakat Desa Ngilngof dilakukan sejak awal objek wisata mulai dikembangkan hingga saat ini, membuat masyarakat Desa Ngilngof yang terlibat dapat menjadi pelaku wisata yang baik.

\section{Analisis Faktor Keberhasilan Pengelolaan Berbasis CBT}

Berdasarkan hasil survey di lapangan mendapatkan hasil dan analisis faktor keberhasilan pengelolaan berbasis Community Based Tourism (CBT), dapat dilihat pada tabel 2 yang dikategorikan oleh penulis menjadi 3 klasifikasi yaitu faktor yang terkait dengan konsep CBT, objek wisata dan wisatawan.

Tabel 2. Analisis dan Klasifikasi Faktor-faktor Keberhasilan Pengelolaan Berbasis CBT

\begin{tabular}{|c|c|c|c|}
\hline No & $\begin{array}{l}\text { Faktor- } \\
\text { faktor }\end{array}$ & Uraian Kondisi Eksisting & $\begin{array}{c}\text { Klasifikasi } \\
\text { Faktor } \\
\text { Keberhasilan }\end{array}$ \\
\hline 1 & $\begin{array}{l}\text { Kepuasan } \\
\text { Wisatawan }\end{array}$ & $\begin{array}{l}\text { Berdasarkan hasil perhitungan dengan metode CSI (Customer } \\
\text { Satisfaction Index) didapatkan nilai kepuasan pengunjung secara } \\
\text { keseluruhan sebesar } 72.34 \% \text { yang berarti pengunjung merasa puas atas } \\
\text { pengelolaan di objek wisata Pantai Ngurbloat. Tingkat kepuasan } \\
\text { pengunjung untuk setiap faktor berada pada rentang yang sama yaitu, } \\
66 \%-80.99 \% \text { yang menandakan pengunjung merasa puas dengan } \\
\text { pengelolaan pada setiap faktor tersebut. }\end{array}$ & Wisatawan \\
\hline 2 & $\begin{array}{l}\text { Hubungan } \\
\text { antar } \\
\text { masyarakat } \\
\text { satu sama } \\
\text { lain }\end{array}$ & $\begin{array}{l}\text { Berdasarkan hasil wawancara dengan Pokdarwis, Masyarakat Ohoi } \\
\text { Ngilngof terlibat dalam pengelolaan objek wisata Pantai Ngurbloat } \\
\text { dengan memiliki peran masing-masing di dalam pengelolaan. } \\
\text { Meskipun memiliki peran masing-masing tetapi terkoordinasi dengan } \\
\text { baik sehingga tidak terdapat kesalahpahaman. selain itu, adanya } \\
\text { kerjasama dengan komunitas Kaki Bajalang yang menunjukkan bahwa } \\
\text { hubungan antar masyarakat Ohoi dengan daerah di luarnya terhubung } \\
\text { dengan baik dan bersama-sama ingin mengembangkan objek wisata } \\
\text { Pantai Ngurbloat }\end{array}$ & Konsep CBT \\
\hline
\end{tabular}

Berdasarkan hasil survey lapangan yang dilakukan, saat ini pada objek wisata Pantai Ngurbloat belum memiliki atraksi kesenian daerah yang disajikan secara rutin pada objek wisata tersebut, dikarenakan pihak pengelola belum mempunyai dana untuk membiayai jika dilakukan

Objek Wisata secara rutin, padahal pertunjukkan kesenian daerah setempat merupakan atraksi yang ditunggu dan ingin dinikmati oleh pengunjung.

Menurut National Geographic dan pengunjung Pantai Ngurbloat. Objek wisata Pantai Ngurbloat merupakan pantai yang memiliki garis pantai terpanjang di Kabupaten Maluku Tenggara dan memiliki karakteristik pasir yang berbeda dengan pantai lainnya dikarenakan memiliki pasir yang halus seperti tepung. Selain itu, Pantai Ngurbloat juga menyajikan keindahan alam baik diatas maupun dibawah laut yang dapat dinikmati oleh para pengunjung.
Objek Wisata 
5

Kepemilikan

lokal
Berdasarkan hasil wawancara dengan Kepala Desa, objek wisata Pantai Ngurbloat menggunakan Tanah Khas Desa (TKD) yang sudah turun temurun dari leluhur sebelumnya dan seluruh karyawan atau pelaku wisata di objek wisata Pantai Ngurbloat merupakan masyarakat Ohoi Ngilngof itu sendiri. Dengan begitu dapat dilihat bahwa masyarakat Ohoi menunjukkan rasa memiliki akan keberadaan objek wisata Pantai Ngurbloat, dengan adanya rasa memiliki maka masyarakat akan berusaha untuk bisa menjaga kelestarian dan mengembangkan objek wisata demi kesejahteraan masyarakat Ohoi.
6

Kepemimpin an lokal
Berdasarkan hasil wawancara Kepala Desa, dengan adanya keberadaan Pemerintah Ohoi Ngilngof, BUMOhoi, Pokdarwis dan Pengelola Ngurbloat merupakan peranan yang penting dengan memiliki perannya masing-masing dalam pengelolaan. Dengan keberadaan perangkat-perangkat tersebut maka masyarakat dapat digerakkan dengan baik dan pembinaan yang baik dalam meningkatkan kemampuan untuk menjadi pelaku wisata dan menjaga hubungan baik antar satu sama lain
Konsep CBT

Konsep CBT

Berdasarkan hasil wawancara Pokdarwis, dukungan masyarakat yang terlihat mulai dari berjalannya pengelolaan terhadap objek wisata Pantai Ngurbloat dimana masyarakat Ohoi mulai terlibat dalam menjadi kepengurusan perangkat mulai dari BUMOhoi, Pokdarwis,

$7 \quad$ Dukungan masyarakat Pengelola. Dengan keterlibatan masyarakat secara langsung menunjukkan bahwa keberadaan objek wisata cukup berpengaruh bagi Ohoi sehingga masyarakat berusaha untuk ikut menjaga dan mengembangkan.

Konsep CBT

Berdasarkan hasil wawancara Kepala Desa, Pemerintah Kabupaten Maluku Tenggara meresmikan Pantai Ngurbloat sebagai destinasi wisata pada tahun 2009 yang menjadikan objek wisata tersebut dapat meningkatkan kesejahteraan masyarakat Ohoi. Maka dari itu,

Skala dikarenakan dari awal perencanaan hingga pengelolaan dilakukan oleh pengembang masyarakat Ohoi maka Pemerintah menyarankan untuk objek wisata an pariwisata tersebut dikelola dengan sistem Community Based Tourism (CBT)

Objek Wisata dengan sudah terbentuknya Pokdarwis untuk mendorong dan membina masyarakat Ohoi. Dengan cara seperti itu, bermaksud untuk keberadaan objek wisata Pantai Ngurbloat dapat bermanfaat dan berdampak bagi kesejahteraan masyarakat Ohoi itu sendiri.

\begin{tabular}{|c|c|c|c|}
\hline 9 & $\begin{array}{c}\text { Kerjasama } \\
\text { antar } \\
\text { stakeholders }\end{array}$ & $\begin{array}{l}\text { Berdasarkan wawancara Kepala Desa, pengelolaan objek wisata Pantai } \\
\text { Ngurbloat melibatkan banyak stakeholders dalam pengelolaan seperti } \\
\text { Pemerintah Ohoi, BUMOhoi, Pokdarwis, Pengelola Ngurbloat, serta } \\
\text { Komunitas Kaki Bajalang. Dengan banyaknya stakeholders tersebut } \\
\text { memiliki peranan masing-masing dalam pengelolaan sehingga dapat } \\
\text { berjalan dengan baik. }\end{array}$ & Konsep CBT \\
\hline 10 & $\begin{array}{c}\text { Dukungan } \\
\text { eksternal } \\
\text { dari } \\
\text { stakeholders }\end{array}$ & $\begin{array}{l}\text { Berdasarkan wawancara manajer pengelola Pantai Ngurbloat, } \\
\text { dukungan eksternal dari berbagai stakeholders didapatkan oleh objek } \\
\text { wisata Pantai Ngurbloat sejak awal pengembangan hingga } \\
\text { pengelolaannya. Dengan adanya dukungan dari pihak Pemerintah } \\
\text { Kabupaten serta PT.Telkom sangat bermanfaat dan menjadikan objek } \\
\text { wisata Pantai Ngurbloat lebih berkembang. }\end{array}$ & Konsep CBT \\
\hline
\end{tabular}


Berdasarkan hasil klasifikasi faktor-faktor keberhasilan pengelolaan berbasis CBT, maka dapat dilihat hasil klasifikasi terbanyak adalah faktor yang terkait dengan konsep CBT sebanyak 6 faktor, kemudian diikuti oleh klasifikasi faktor yang terkait dengan objek wisata sebanyak 3 faktor dan klasifikasi faktor yang terkait dengan wisatawan sebanyak 1 faktor. Dengan klasifikasi faktor yang terkait konsep CBT sebanyak 6 faktor menunjukkan bahwa 6 faktor tersebut merupakan faktor-faktor yang terpenting dari 10 faktor yang ada dalam faktor keberhasilan pengelolaan objek wisata berbasis CBT. Tabel 3 menunjukkan faktor-faktor keberhasilan yang telah diklasifikasi berdasarkan penjabaran diatas.

Tabel 3. Faktor-faktor Keberhasilan Pengelolaan Berdasarkan Klasifikasi

\begin{tabular}{lll}
\hline \multicolumn{1}{c}{ Konsep CBT } & \multicolumn{1}{c}{ Objek Wisata } & Wisatawan \\
\hline $\begin{array}{ll}\text { Hubungan antar masyarakat satu sama } \\
\text { lain }\end{array}$ & Keaslian lokal & $\begin{array}{l}\text { Kepuasan } \\
\text { wisatawan }\end{array}$ \\
\hline Kepemilikan lokal & Keunikan lokal & \\
\hline Kepemimpinan lokal & Skala pengembangan pariwisata & \\
\cline { 1 - 2 } Dukungan masyarakat & & \\
\hline Kerjasama antar stakeholder & & \\
\hline Dukungan eksternal dari stakeholders & & \\
\hline
\end{tabular}

Sumber : Hasil Olahan Penulis, 2021

Dari faktor-faktor yang berada dalam klasifikasi konsep CBT, terdapat prioritas berdasarkan skala kepentingan yang ada pada kondisi eksisting pada objek wisata Pantai Ngurbloat, sebagai berikut :

1. Kepemilikan lokal

2. Kepemimpinan lokal

3. Dukungan masyarakat

4. Kerjasama antar stakeholders

5. Dukungan eksternal dari stakeholders

6. Hubungan antar masyarakat satu sama lain

\section{KESIMPULAN DAN SARAN}

\section{Kesimpulan}

Objek wisata Pantai Ngurbloat merupakan objek wisata bahari di Kabupaten Maluku yang menerapkan pengelolaan berbasis Community Based Tourism (CBT) dengan memiliki 3 potensi daya tarik wisata. Potensi daya tarik wisata yang dapat dilihat berupa keindahan pemandangan alam berupa pemandangan matahari terbenam dan keindahan bawah laut. Dengan memiliki kelebihan pada keindahan alam, dapat pula kegiatan yang dapat dilakukan di objek wisata, seperti melakukan snorkeling untuk melihat keindahan bawah laut, menikmati kuliner khas daerah setempat, dan dapat mengabadikan foto di spot-spot foto yang telah disediakan. Terdapat pula beberapa fasilitas yang disediakan di sekitar kawasan objek wisata Pantai Ngurbloat, salah satunya cottage yang memiliki tema/suasana yang berbeda tiap cottagenya.Terdapat beberapa oleh-oleh yang tersedia di objek wisata Pantai Ngurbloat yang dapat dijadikan cenderamata setelah berkunjung di objek wisata, seperti kaos, akar bahar, mutiara asin, kerajinan kulit kerang dan beberapa makanan khas daerah seperti embal dan kacang botol

Berdasarkan hasil penyebaran kuesioner pada objek wisata Pantai Ngurbloat, memiliki nilai CSI (Customer Satisfaction Index) sebesar $72.34 \%$ yang memiliki arti wisatawan yang berkunjung ke objek wisata Pantai Ngurbloat merasa puas dengan pengelolaan yang didapatkan. Pengelolaan yang dilakukan pada objek wisata Pantai Ngurbloat telah memenuhi aspek-aspek pendekatan Community Based Tourism (CBT), yaitu dengan adanya dukungan pemerintah, terwujudnya partisipasi masyarakat, pembagian keuntungan yang adil, penggunaan sumber daya lokal secara berkesinambungan serta penguatan institusi lokal. 
Terdapat 10 faktor-faktor keberhasilan pengelolaan berbasis Community Based Tourism (CBT) yang diklasifikasikan menjadi 3 faktor yaitu faktor terkait dengan konsep CBT, faktor terkait dengan objek wisata dan faktor terkait wisatawan. Berdasarkan hasil analisis faktor-faktor keberhasilan, terdapat 6 faktor terkait konsep CBT yang mempengaruhi keberhasilan pengelolaan berbasis CBT yaitu faktor adanya kepemilikan lokal, kepemimpinan lokal, terdapat dukungan masyarakat, terjalinnya kerjasama antar stakeholder, adanya dukungan eksternal dari stakeholder serta terjalinnya hubungan yang baik antar masyarakat satu sama lainnya.Salah satu faktor yang mempengaruhi yaitu terjalinnya kerjasama antar stakeholders, seperti adanya kerjasama antar pokdarwis Ngurbloat dengan pengelola Pantai Ngurbloat dalam pendekatan kepada masyarakat Desa terkait dengan pengelolaan objek wisata. .

\section{Saran}

Melalui penelitian ini, penulis melihat adanya potensi untuk melakukan penambahan akses menuju objek wisata Pantai Ngurbloat menggunakan transportasi umum agar memudahkan pengunjung. Selain itu, Menambahkan tingkat kualitas dalam beberapa fasilitas, seperti ketersediaannya tempat parkir dan balai kesenian Ngurbloat serta menyediakan kegiatan baru yang dapat dilakukan pada objek wisata Pantai Ngurbloat berupa kegiatan water sport, pertunjukkan kesenian setempat dan menambahkan fasilitas baru seperti ATM Center

Untuk meningkatkan kualitas dalam pengelolaan objek wisata Pantai Ngurbloat dapat dimulai dari faktor-faktor yang sangat mempengaruhi seperti faktor terkait dengan konsep CBT yaitu memperkuat rasa kepemilikan lokal dalam masyarakat, meningkatkan dan mempertahankan kepemimpinan lokal, meningkatkan dukungan masyarakat, meningkatkan kerjasama antar stakeholders, meningkatkan dukungan eksternal dari stakeholders, dan meningkatkan pula hubungan antar masyarakat satu sama lain. Setelah faktor utama telah terpenuhi, kemudian mulai meningkatkan faktor terkait dengan objek wisata seperti menunjukkan keaslian lokal, menjaga keunikan lokal dan memperluas skala pengembangan pariwisata serta meningkatkan terkait dengan faktor wisatawan.

Mempertahankan atau meningkatkan kualitas dari pengelolaan seperti mempertegas akan aturanaturan yang diberlakukan di objek wisata, mengajak serta menyediakan fasilitas tempat berkumpul untuk pokdarwis dan memperluas partisipasi masyarakat dalam pengelolaan, agar tidak hanya masyarakat Desa Ngilngof saja yang berkontribusi tetapi masyarakat desa sekitarnya juga dapat berkontribusi.

\section{REFERENSI}

A.J, M. (2012). Kepariwisataan dan Perjalanan. Jakarta: Raja Grafindo Persada.

Dirjen Pengembangan Wisata Kementerian Pariwisata dan Ekonomi Kreatif. (2012). Buku Pedoman Kelompok Sadar WIsata.

Karacaoğlu, S., \& Birdir, K. (2017). Success Factors of Community Based Tourism (CBT) Perceived by Local Peoples: The Case of \% 100 Misia Project. Internasional Rural Tourism and Development Journal, E-ISSN: 2602-4462,1(2): 53-61.

Soekanto, S. (2007). Sosiologi Suatu Pengantar. Jakarta: Raja Grafindo Persada.

Suansri, P. (2003). Community Based Tourism Handbook. Thailand: REST Project.

Suwartoro, G. (1997). Dasar-dasar Pariwisata. Yogyakarta: Andi Offset.

Undang - Undang tentang Kepariwisataan. (UU No. 10 Tahun 2009). Jakarta: Direktorat Jendral Hukum dan HAM.

Warpani, S., \& Warpani, I. (2007). Pariwisata Dalam Tata Ruang Wllayah. Bandung: ITB.

Yaman, A., \& Mohd, A. (2004). Community Based Ecotourism : New Proposition for Sustainable Development and Environment Conservation in Malaysia. Journal of Applied Science IV, 583589.

Yoeti, O. (1996). Pengantar Ilmu Pariwisata. Bandung: Angkasa.

Yoeti, O. (2010). Dasar-dasar Pengertian Hospitality Pariwisata. Bandung: PT. Alumni. 